Cukurova Üniversitesi Mühendislik Mimarlık Fakültesi Dergisi, 35(1), ss. 59-66, Mart 2020

Çukurova University Journal of the Faculty of Engineering and Architecture, 35(1), pp. 59-66, March 2020

\title{
Peyniraltı Suyunun Koagülasyon/Flokülasyon Yöntemiyle Arıtılmasında Doğal Bir Koagülant Olan Montmorillonitin Kullanılması
}

\author{
Ayşe ÖZGÜVEN ${ }^{1}$, Tuba BAYRAM ${ }^{* 1}$, Dilara ÖZTÜRK ${ }^{1}$, Erdinç ALADAĞ $^{1}$ \\ ${ }^{I}$ Van Yüzüncü Yıl Üniversitesi, Mühendislik Fakültesi, Çevre Mühendisliği Bölümü, Van
}

Geliş tarihi: $18.12 .2019 \quad$ Kabul tarihi: 15.05 .2020

$\ddot{\mathbf{O} z}$

$\mathrm{Bu}$ çalışmada süt endüstrisi atıksularından kaynaklanan peyniraltı suyunun koagülasyon/flokülasyon yöntemiyle kimyasal arıtımı amaçlanmıştır. Peyniraltı suyunun kimyasal arıtımı, jar testi deneyleriyle yürütülerek en iyi $\mathrm{pH}$ aralığında optimum koagülant cinsi ve dozu belirlenmiştir. $\mathrm{pH}(4,0-8,5)$ ve koagülant dozunun $(0,25-2,0 \mathrm{~g} / \mathrm{L})$ KOİ (kimyasal oksijen ihtiyacı) giderim verimine etkisini incelemek üzere kesikli deneyler yapılmıştır. Koagülant olarak demir sülfat, alüminyum sülfat (alum) ve kil (montmorillonit) kullanılmıştır. Optimum koagülant dozu $1,0 \mathrm{~g} / \mathrm{L}$ ve pH 7,0 olarak belirlenmiştir. Kil, alum+kil, demirsülfat+kil için sırasıyla $\% 88, \% 91$ ve $\% 92$ KOİ giderim verimi ve $\% 89, \% 93$ ve $\% 95$ AKM (askıda katı madde) giderim verimi elde edilmiş̧ir. Yapılan kimyasal arıtma deneylerinde montmorillonitin diğer koagülantlarla birlikte ön arıtım amacıyla kullanılabileceği sonucuna varılmıştır. Ancak su kirliliği kontrol yönetmeliğinde belirtilen deşarj standartları sağlanamadığı için kimyasal arıtımın sadece kendinden sonraki ünitenin yükünü hafifleteceği tespit edilmiştir.

Anahtar Kelimeler: Koagülasyon/flokülasyon, Koagülant, Peyniraltı suyu, Atıksu

\section{The Use of Montmorillonite, A Natural Coagulant, for The Treatment of Whey by Coagulation/Flocculation Method}

\begin{abstract}
In this study, chemical treatment of whey originating from dairy industry wastewaters by coagulation/flocculation method was aimed. The chemical treatment of whey was carried out with jar test experiments and optimum coagulant type and dosage were determined in the best $\mathrm{pH}$ range. Batch experiments were performed to investigate the effect of $\mathrm{pH}(4.0-8.5)$ and coagulant dose $(0.25-2.0 \mathrm{~g} / \mathrm{L})$ on COD (chemical oxygen demand) removal efficiency. Iron sulfate, aluminum sulfate (alum) and clay (montmorillonit) were used as coagulants. Optimum dose of coagulant was $1.0 \mathrm{~g} / \mathrm{L}$ and $\mathrm{pH}$ 7.0. For clay, alum + clay, iron sulphate + clay, $88 \%, 91 \%$ and $92 \%$ COD removal efficiency and $89 \%, 93 \%$ and $95 \%$ SS (suspended solid) removal efficiency were obtained respectively. In the chemical treatment experiments, it was concluded that montmorillionite can be used together with other coagulants for pretreatment. However, since the discharge standards specified in the water pollution control regulation could not be met, it was determined that chemical treatment would only relieve the load of the next unit.
\end{abstract}

Keywords: Coagulation/flocculation, Coagulant, Whey, Wastewater

*Sorumlu yazar (Corresponding author): Tuba BAYRAM, tubabayram@yyu.edu.tr 


\section{GíRiş}

Endüstrilerin hızlı büyümesi ve kentleşmeden dolayı, çevresel ortamlarda toksik maddelerin salınımı giderek artmakta ve su kirliliği ciddi bir endişe kaynağı haline gelmektedir [1]. Organik maddeler (aromatik bileşikler, proteinler, yă ve gres, fenoller, pestisitler, vb.) ve ağır metaller (arsenik, kadmiyum, kurşun, nikel vb.) alıcı ortamlarda olumsuz çevresel koşullara neden olmaktadır [2-3]. Bu sebeple atıksuların arıtımı konusunda çalışmaların yapılması gerekmektedir [4].

Biyolojik çeşitlilik için ciddi bir tehlike olan süt atıksuları her yıl, dünya çapında, 4-11 milyon ton arasında ortaya çıkmaktadır. Süt atıksularının arıtılmadan alıcı ortamlara deşarj edilmesinin yol açtığ 1 ciddi sorunlardan biri de yağ ve gresin su yüzeyinde oksijen transferini engellemesi, çözünmüş oksijen tükenmesi ve daha sonra burada yaşayan hayvanlar ve bitkiler için olumsuz çevresel koşullara neden olmasıdır [5]. Diğer endüstrilerle karşılaştırıldığında, süt endüstrisi kirletici potansiyeli fazla olan büyük miktarda atıksu üreten endüstrilerden biridir [6-7].

Süt endüstrisi çiğ sütün farklı prosesler (pastörizasyon, soğutma, vb.) tarafindan yoğurt, tereyağı, peynir gibi ürünlere dönüştürülmesini ve üretilmesini içermektedir. Peynir yapma sürecinde birçok adım vardır. Bunlar arasında sütün çökeltilmesi, lor haline getirilmesi, pişirilmesi, peynir kalıplarına lor koyulması ve kalıpların preslenmesi yer almaktadır. Bu aşamada en önemli atıksu kaynağı peyniraltı suyudur. Peyniraltı suyu kazein ve yağın sütten çökeltilerek alınması işleminde ortaya çıkan yeşilimsi sarı renkli bir sıvıdır. Bununla birlikte, peyniraltı suyu süt işleme tesislerinde çoğunlukla kurutulduktan sonra hayvan yemi olarak veya tarım ve gida endüstrilerinde ham madde olarak yeniden kullanılmaktadır [8].

Peynir üretim endüstrisi, üç temel atıksu türünden sorumludur; i) peyniraltı suyu (peynir üretiminden kaynaklanan), ii) ikinci peyniraltı suyu (süzme peynir üretiminden kaynaklanmaktadır), iii) peyniraltı suyu üretiminde kullanılan tankların ve boruların yıkanması sonucu oluşan atıksudur. Peyniraltı suyu bileşiminde yüksek kimyasal oksijen ihtiyacına (KOİ) neden olan laktoz (\%70-75), çözünür proteinler (\%10-15), yüksek konsantrasyonlarda askıda katı madde, klorür ve sodyum tespit edilmiştir ve bu da potansiyel bir çevresel risk oluşturmaktadır [9].

Süt endüstrisi atıksularının özellikleri, nihai ürünlere, sistem tipine ve üretim planında kullanılan çalışma yöntemlerine bağlı olarak önemli ölçüde değişebilir. Son on yılda, süt endüstrisi atıksularının arıtılması için çeşitli teknolojiler geliştirilmiştir. Süt endüstrisi atıksuları yüksek oranda biyolojik olarak parçalanabilmesi nedeniyle biyolojik atıksu arıtma sistemleri ile etkin bir şekilde arıtılmakta ancak uygun şekilde arıtılmadığında çevresel bir tehlikeye neden olabilmektedir [10].

Aerobik ve anaerobik prosesler, koagülasyon/flokülasyon yöntemleri, nanofiltrasyon, ters ozmoz ve membran prosesleri gibi farklı arıtma yöntemleri, atıksuda bulanıklığa neden olan askida ve kolloidal partiküllerin gideriminde kullanılmaktadır [11].

Koagülasyon-flokülasyon, flotasyon gibi kimyasal arıtma yöntemleri atıksu arıtımında organik madde, bulanıklık, ağır metal, renk giderimi için kullanılmaktadır [12]. Kimyasal arıtma prosesleri biyolojik sistemler ile karşılaştırıldığında, işletiminin kolay olması, organik maddenin çökeltilerek giderilebilmesi, atıksu debisi ve içeriğinden etkilenmemesi gibi avantajları nedeniyle endüstriyel atıksu arıtımında tercih edilmektedir [13].

Kimyasal olarak sentezlenen kogülantlar (inorganik polimerler ve alüminyum tuzları) düşük maliyetleri nedeniyle atıksu arıtımında yaygın olarak kullanılmaktadır. Fakat bu kogülantlar fazla çamur üretimine neden olmakta ve doğası gereği parçalanamadıkları için birçok çevresel sorunları da beraberinde getirmektedir. Bu nedenle kirlilik yükü yüksek endüstriler tarafından kullanılan geleneksel koagülantların yerini alabilecek etkili, ekonomik ve çevre dostu koagülant maddeler için 
çalışmalar yapılmaktadır. Atıksu arıtma maliyetinin düşürülmesi, çevresel sürdürülebilirlik açısından son zamanlarda büyük önem kazanmıştır [14].

Farklı bölgelerden elde edilen kil grubu minerallerin, toksik kirleticilerin gideriminde kullanılabileceğine dair çalışmalar bulunmaktadır [15-16].

$\mathrm{Bu}$ çalışma kapsamında Atatürk Üniversitesi’nde bulunan pilot süt fabrikasından atıksu numuneleri alınmıştır. İlk önce atıksuyun karakterizasyon çalışması için analizler yapılmıştır. Koagülasyon/flokülasyon yönteminde kullanılan kimyasallara alternatif olarak doğal bir kil olan montmorillonitin koagülant olarak kullanılabilirliği araştırılmıştır. Koagülasyon/flokülasyon deneyleri jar-test cihazı ile yapılmıştır. Koagülant olarak demir sülfat, alum ve kil kullanılarak optimum $\mathrm{pH}$ değerleri tespit edilmiştir. KOİ giderim veriminin deşarj kriterlerini sağlayıp sağlamadığını kontrol etmek için Su Kirliliği Kontrol Yönetmeliği'nde verilen deşarj limitleri ile değerlendirilmiştir.

\section{MATERYAL VE METOT}

\subsection{Atıksu Kaynakları ve Karakterizasyonu}

Süt üretimi yapan tesislerin atıksularının karakterizasyonu üretim prosesine göre değişir. Atıksuların nispeten düşük $\mathrm{pH}$ ve yüksek tuzluluk oranı, peynir üretimi sırasında ilave edilen $\mathrm{NaCl}$ miktarına bu endüstride üretilen peyniraltı suyunun türüne ve bağlıdır [17].

Peyniraltı suyunun fiziksel ve kimyasal karakterizasyon değerleri Çizelge 1'de gösterilmiştir. Peyniraltı suyunun $\mathrm{pH}$ değerinin 3,3-9,0; askıda katı madde (AKM), toplam azot (TN) ve toplam fosfor (TP) değerleri ise sirasiyla $0,1-22,0,0,01-1,7$ ve $0,006-0,5 \mathrm{~g} / \mathrm{L}$ aralığında olduğu bildirilmiştir. TN ve TP içeriği nedeniyle peynir atıksuları özellikle göller ve yavaş hareket eden nehirler gibi alıcı ortamlarda önemli bir ötrofikasyon riski oluşturmaktadır. Ayrıca, 0,06 ile $0,27 \mathrm{~g} / \mathrm{L}$ arasında değişen amonyum azotu $\left(\mathrm{NH}_{4}-\mathrm{N}\right)$ konsantrasyonu, sucul yaşam için toksik etkilere neden olabilir [18-19].

Çizelge 1. Peyniraltı suyunun fiziksel ve kimyasal karakterizasyon değerleri

\begin{tabular}{|l|c|c|c|c|c|c|}
\hline Parametre & {$[20]$} & {$[21]$} & {$[22]$} & {$[23]$} & {$[24]$} & {$[25]$} \\
\hline $\mathrm{pH}$ & 5 & - & 4,9 & 4,2 & $3,8-6,3$ & $6-6,5$ \\
\hline $\mathrm{TKM}(\mathrm{g} / \mathrm{L})$ & 56,8 & - & 66,83 & 70,9 & - & $55-65$ \\
\hline $\mathrm{AKM}(\mathrm{g} / \mathrm{L})$ & 21,82 & - & 22,15 & - & $4,1-10$ & $10-15$ \\
\hline $\mathrm{TN}(\mathrm{g} / \mathrm{L})$ & & & & 1,76 & - & \\
\hline $\mathrm{NO}_{3}(\mathrm{mg} / \mathrm{L})$ & - & 9,1 & - & - & - & 10 \\
\hline $\mathrm{TKN}^{(\mathrm{g} / \mathrm{L})}$ & 0,5 & $1,46 \pm 0,26$ & 1,49 & - & - & $0,01-0,02$ \\
\hline $\mathrm{NH}_{4}-\mathrm{N}(\mathrm{g} / \mathrm{L})$ & 0,27 & 0,064 & 0,17 & - & - & - \\
\hline $\mathrm{TP}(\mathrm{g} / \mathrm{L})$ & - & $0,38 \pm 0,05$ & - & - & - & - \\
\hline $\mathrm{KOI}(\mathrm{g} / \mathrm{L})$ & 75,8 & $60-80$ & 74,2 & 102,1 & $60,3-66,7$ & $50-70$ \\
\hline BOI் $(\mathrm{g} / \mathrm{L})$ & $40-60$ & $30-50$ & - & - & 35,5 & $27-36$ \\
\hline
\end{tabular}

\subsection{Kullanılan Kil ve Özellikleri}

$\mathrm{Bu}$ çalışmada, koagülant olarak doğal kil kullanılmıştır. Montmorillonit (MMT), minerolojik özelliğine göre simektit grubuna, kimyasal olarak silikat içerikli gruba, yapısına göre kristal kil minerallerinin üç tabakalı kil minerali grubuna dahildir. Kil, $110{ }^{\circ} \mathrm{C}$ 'de etüvde kurutulmuştur. Çalışma boyunca kil konsantrasyonu 1,0 g/L sabit tutulmuştur.

\subsection{Analitik Yöntem}

Atıksu karakterizasyonunun belirlenmesi; kanalizasyon sistemleri, arıtma tesisleri ve deşarj ünitelerinin tasarımı ve işletimi için gereklidir [26]. Peyniraltı suyu karakterizasyon parametreleri ( $\mathrm{pH}$, sicaklık, iletkenlik, $\mathrm{AKM}, \mathrm{SO}_{4}^{-2}, \mathrm{KOI}, \mathrm{NO}_{3}{ }^{-}$, $\left.\mathrm{NH}_{4} \mathrm{~N}, \mathrm{PO}_{4}-\mathrm{P}, \mathrm{TOK}, \mathrm{TN}\right)$, standart yöntemlere göre analitik teknikler kullanılarak laboratuvarda analiz edilmiştir. Peyniraltı suyu karakterizasyon 
parametrelerinin analitik yöntemi, birimi ve kısaltması Çizelge 2'de gösterilmiştir [27].

Çizelge 2. Peyniraltı suyu atıksu parametrelerinin analitik yöntemi, birimi ve kısaltması

\begin{tabular}{|c|c|c|c|}
\hline Parametre & Kisaltma & Birim & Analitik Metod \\
\hline Sicaklık & $\mathrm{T}$ & ${ }^{\circ} \mathrm{C}$ & Multimetre probu \\
\hline $\mathrm{pH}$ & $\mathrm{pH}$ & - & $\begin{array}{l}\text { Potansiyometrik/pH } \\
\text { probu }\end{array}$ \\
\hline İletkenlik & Eİ & $\mathrm{mS} / \mathrm{cm}$ & Multimetre probu \\
\hline $\begin{array}{l}\text { Askıda } \\
\text { katı } \\
\text { madde } \\
\end{array}$ & $\mathrm{AKM}$ & $\mathrm{mg} / \mathrm{L}$ & $\begin{array}{l}\text { Fotometrik yöntem } \\
\text { (Spektrofotometre ile) }\end{array}$ \\
\hline Sülfat & $\mathrm{SO}_{4}^{-2}$ & $\mathrm{mg} / \mathrm{L}$ & $\begin{array}{l}\text { Spektrofotometrik } \\
\text { Yöntem }\end{array}$ \\
\hline Fosfat & $\mathrm{PO}_{4}-\mathrm{P}$ & $\mathrm{mg} / \mathrm{L}$ & $\begin{array}{l}\text { Spektrofotometrik } \\
\text { Yöntem }\end{array}$ \\
\hline $\begin{array}{l}\text { Toplam } \\
\text { azot }\end{array}$ & $\mathrm{TN}$ & $\mathrm{mg} / \mathrm{L}$ & $\begin{array}{l}\text { Katalitik termal } \\
\text { dekompozisyon } \\
\text { yöntemi }\end{array}$ \\
\hline $\begin{array}{l}\text { Nitrat } \\
\text { azotu }\end{array}$ & $\mathrm{NO}_{3}^{-}$ & $\mathrm{mg} / \mathrm{L}$ & İyon Kromotografisi \\
\hline Klorür & $\mathrm{Cl}^{-}$ & $\mathrm{mg} / \mathrm{L}$ & Titrimetrik Yöntem \\
\hline $\begin{array}{l}\text { Amonyum } \\
\text { azotu }\end{array}$ & $\mathrm{NH}_{4}-\mathrm{N}$ & $\mathrm{mg} / \mathrm{L}$ & $\begin{array}{l}\text { Spektrofotometrik } \\
\text { Yöntem }\end{array}$ \\
\hline $\begin{array}{l}\text { Kimyasal } \\
\text { oksijen } \\
\text { İhtiyacı } \\
\end{array}$ & KOİ & $\mathrm{mg} / \mathrm{L}$ & $\begin{array}{l}\text { Closed Reflux Metod, } \\
\text { Titrimetrik Yöntem }\end{array}$ \\
\hline $\begin{array}{l}\text { Toplam } \\
\text { organik } \\
\text { karbon }\end{array}$ & TOK & $\mathrm{mg} / \mathrm{L}$ & $\begin{array}{l}\text { TOC-L katalitik } \\
\text { oksidasyon yöntemi }\end{array}$ \\
\hline
\end{tabular}

Tesiste bir günde yaklaşık $900 \mathrm{~kg}$ süt ürünleri üretilmektedir. Ayrıca, üretim sonucu tesisten çıkan günlük atıksu miktarı 1,5-2 $\mathrm{m}^{3}$ atıksu/ton'dur. Atıksu numuneleri analiz edilinceye kadar $4{ }^{\circ} \mathrm{C}$ 'de bekletilmiştir ve ISO 17025 kalite sistemiyle akredite edilmiş bir laboratuvarda analiz edilmiştir (Çizelge 3).

Çizelge 3. Pilot tesisten alınan peyniraltı suyunun karakterizasyonu

\begin{tabular}{|l|l|}
\hline Parametre & Konsantrasyon \\
\hline $\mathrm{pH}$ & 4,6 \\
\hline $\mathrm{T}\left({ }^{\circ} \mathrm{C}\right)$ & 10,8 \\
\hline $\mathrm{EI}(\mathrm{mS} / \mathrm{cm})$ & 23 \\
\hline $\mathrm{KO} \dot{\mathrm{I}}(\mathrm{mg} / \mathrm{L})$ & 89095 \\
\hline $\mathrm{AKM}(\mathrm{mg} / \mathrm{L})$ & 25000 \\
\hline $\mathrm{TOK}(\mathrm{mg} / \mathrm{L})$ & 34508 \\
\hline $\mathrm{NO}_{3}(\mathrm{mg} / \mathrm{L})$ & 16,63 \\
\hline $\mathrm{PO}_{4}-\mathrm{P}(\mathrm{mg} / \mathrm{L})$ & 1237,17 \\
\hline $\mathrm{SO}_{4}{ }^{-2}(\mathrm{mg} / \mathrm{L})$ & 267,53 \\
\hline $\mathrm{Cl}^{-}(\mathrm{mg} / \mathrm{L})$ & 1453,54 \\
\hline $\mathrm{NH}_{4}-\mathrm{N}(\mathrm{mg} / \mathrm{L})$ & 62,132 \\
\hline $\mathrm{TN}(\mathrm{mg} / \mathrm{L})$ & 1399 \\
\hline
\end{tabular}

Koagülasyon/flokülasyon deneyleri için dörtlü jartest cihazı kullanılmıştır. Atıksuyun $\mathrm{pH}$ ayarı için $1 \quad \mathrm{~N}_{2} \mathrm{SO}_{4}$ veya $1 \mathrm{~N} \mathrm{NaOH}$ kullanımı tercih edilmiştir. Alum, demirsülfat ve montmorillionit kili koagülant olarak kullanılmıştır. Deneyler, optimum koagülant cinsi ve dozajını veren en iyi $\mathrm{pH}$ aralığında yapılmıştır. $500 \mathrm{ml}$ peyniraltı suyu numunesi bulunan behere seçilen koagülantlar dozlanmıştır. Jar testi cihazında 100 rpm'de 5 dakika hızlı karıştırma, 20 rpm'de 15 dakika yavaş karıştırma işleminden sonra peyniraltı suyunun çöktürülmesi için 30 dakika bekletilmiştir. Daha sonra atıksuyun süpernatant kısmından alınan örneklerde Standart Metotlara [27] göre KOİ, AKM, pH analizleri yapılmıştır. Koagülasyon parametrelerinin optimizasyonu için jar testleri 4,0-8,5 aralığında ve koagülant dozajı 0,25-2,0 g/L aralığında belirlenen değerlerde yürütülmüştür. Deneysel çalışmanın ilk aşamasında 1,0 g/L alum, demirsülfat ve montmorillionit kili kullanıldığında pH değeri 4,0, 5,5, 7,0 ve 8,5'a ayarlanmıştır. Sonraki aşamada ise belirlenen optimum $\mathrm{pH}$ değeri kullanılarak optimum koagülant dozajını belirlemek amaciyla $0,25, \quad 0,5, \quad 1,0, \quad 1,5 \quad$ ve $2,0 \quad \mathrm{~g} / \mathrm{L}$ konsantrasyonlarında koagülant kullanılmıştır.

\section{BULGULAR VE TARTIŞMA}

Süt endüstrisinden kaynaklanan peyniraltı suyunun kirlilik yükünün yüksek olması nedeniyle alıcı ortama verilmeden önce arıtılması ve Su Kirliliği Kontrolü Yönetmeliği'nde [28] belirtilen deşarj standartları sağlandıktan sonra deşarj edilmesi gerekmektedir. Yönetmelikte bulunan süt üretimi yapan işletmelerin, atıksularının arıtımı yapıldıktan sonra alıcı ortamlara verildiğinde gereken deşarj standartları Çizelge 4'de verilmiştir.

Çizelge 4. Sektör gıda sanayi (Süt ve süt ürünleri) [27]

\begin{tabular}{|l|c|c|c|}
\hline Parametreler & Birim & $\begin{array}{c}\text { Komposit } \\
\text { Numune } \\
\text { 2 Saatlik }\end{array}$ & $\begin{array}{c}\text { Komposit } \\
\text { Numune } \\
\text { 24 Saatlik }\end{array}$ \\
\hline KOI & $(\mathrm{mg} / \mathrm{L})$ & 150 & 160 \\
\hline Yağ ve gres & $(\mathrm{mg} / \mathrm{L})$ & 60 & 30 \\
\hline $\mathrm{pH}$ & & $6-9$ & $6-9$ \\
\hline
\end{tabular}

Literatürde peyniraltı suyunun arıtımında kullanılan koagülantlar ve uygulamaları koşulları Çizelge 5'de verilmiştir. 
Çizelge 5. Peyniraltı suyunun arıtımında kullanılan koagülantlar ve uygulama koşulları [29]

\begin{tabular}{|l|c|c|c|c|c|c|}
\hline \multirow{2}{*}{$\begin{array}{l}\text { Koagülant } \\
\text { cinsi ve } \\
\text { dozaj1 }\end{array}$} & $\mathrm{pH}$ & \multirow{2}{*}{$\begin{array}{c}\mathrm{T} \\
\left({ }^{\circ} \mathrm{C}\right)\end{array}$} & \multicolumn{4}{|c|}{ Giderim (\%) } \\
\cline { 4 - 7 } & & & KOİ & BOİ & TKN & $\mathrm{P}$ \\
\hline $\begin{array}{l}\text { Alum } \\
(1,0 \mathrm{~g} / \mathrm{L})\end{array}$ & 7,0 & 10 & 35 & 36 & 44 & 77 \\
\hline $\begin{array}{l}\text { Demirsülfat } \\
(0,25 \mathrm{~g} / \mathrm{L})\end{array}$ & 8,5 & 10 & 43 & 67 & 43 & 89 \\
\hline $\begin{array}{l}\mathrm{FeCl}_{3} \\
(0,25 \mathrm{~g} / \mathrm{L})\end{array}$ & 4,4 & 10 & 32 & 23 & 19 & 14 \\
\hline
\end{tabular}

\section{1. pH Etkisi}

Deneysel çalışmada her atıksu numunesinin başlangıç pH değeri 6-8 aralığındadır. Asidik veya bazik ortamlara kil eklendiğinde zamana bağlı olarak pH değeri değişmektedir. Koagülant ilavesinin, çözeltinin pH'sini düşüren $\mathrm{H}^{+}$ iyonlarının salınmasına yol açtığı iyi bilinmektedir. $\mathrm{pH}$ azalmasının nedeni; $\mathrm{H}^{+}$iyonlarla $\mathrm{SiO}^{-}, \mathrm{AlO}^{-}$ gruplarındaki (-) yüklerin kilin yüküyle yer değiştirmesinden kaynaklandığı düşünülmektedir [30]. Alum, demirsülfat ve montmorillionit kili kullanılarak yapılan jar testi sonucunda $\mathrm{pH}$ 'nın KOİ ve AKM giderimine etkisi Şekil 1 ve Şekil 2'de verilmiştir.

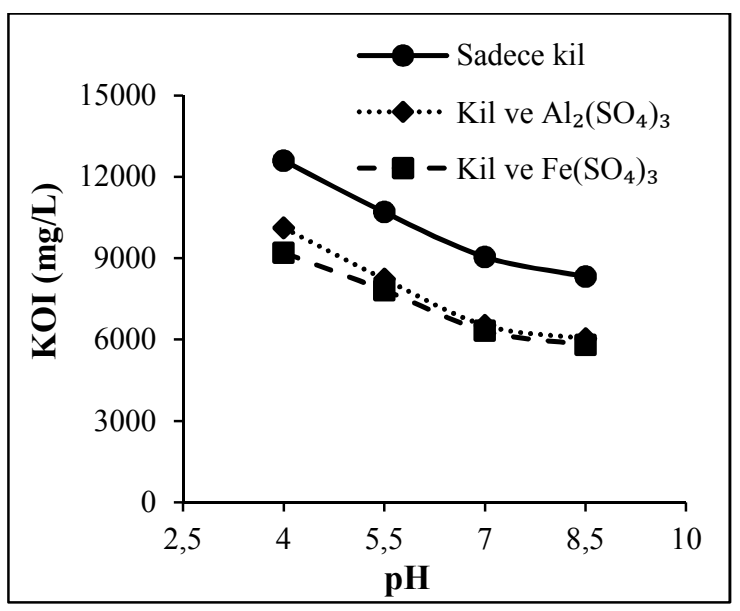

Şekil 1. KOİ giderimine $\mathrm{pH}$ değerinin etkisi

Bütün koagülantlar için optimum $\mathrm{pH}$ değeri 7,0 olarak bulunmuştur. Üç farklı koagülant kullanılarak yapılan jar testi deneyinde $\mathrm{pH}$ 7,0 değerinde $1,0 \mathrm{~g} / \mathrm{L}$ montmorillionit $\mathrm{kili}+\mathrm{FeSO}_{4}$ kullanıldığında en yüksek KOİ giderme verimi (\%92) elde edilmiştir. Süt endüstrisi atıksularına 0,2-1,8 g/L aralığında koagülant olarak alum ve demir sülfat uygulanan bir çalışmada $\mathrm{pH}$ 5,0'de sırasıly $\% 68$ ve $\% 62$ KOİ giderme verimi elde edilmiştir [31]. Koagülant olarak kaolinit kilinin kullanıldığı diğer bir çalışmada ise $\mathrm{pH} 7,0$ değerinde $1,0 \mathrm{~g} / \mathrm{L}$ kaolinit dozunda \%94 KOİ giderim verimi bildirilmiştir. Maksimum KOİ gideriminin elde edildiği kaolinit dozunda $\left(\begin{array}{ll}1,0 & \mathrm{~g} / \mathrm{L}\end{array}\right) \quad \% 17$ oranında AKM giderimi sağlanmıştır [32].

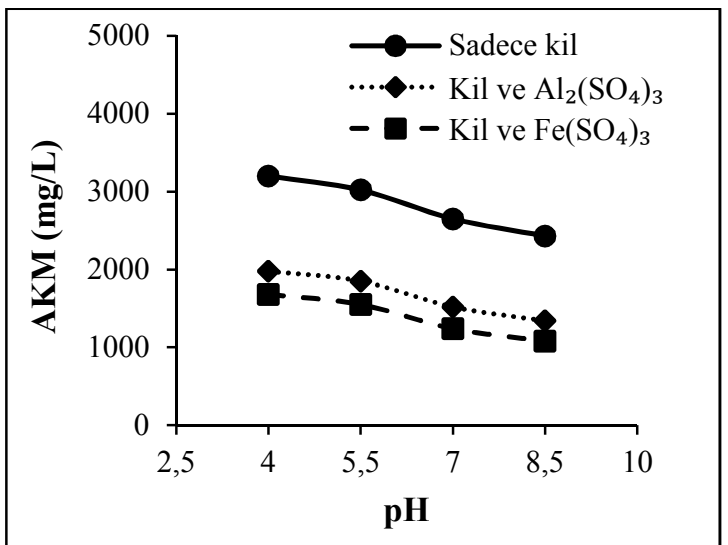

Şekil 2. AKM giderimine $\mathrm{pH}$ değerinin etkisi

Sadece kil, Alum+kil, demirsülfat + kil kullanılarak KOİ giderme verimleri sırasıyla, $\% 88, \% 91$ ve $\% 92$ olarak bulunurken, AKM giderme verimleri sirasiyla $\% 89, \% 93$ ve $\% 95$ olarak bulunmuştur. Özellikle montmorillonit kili demir sülfat ile birlikte kullanıldığında yüksek giderim verimleri elde edilmiştir. Yapılan deneylerde, montmorillonitin suda bulunan çözünmüş, askıda, kolloidal maddelerin koagülasyon-flokülasyon işlemi ile en iyi çökeltiminin sağlandığı koagülant olarak belirlenmiştir. Peyniraltı suyunun kimyasal arıtımı ilgili yapılan bir çalışmada koagülasyon/ flokülasyon prosesinde koagülant olarak alum demir (III) klorür ve demir (II) sülfat kullandığında maksimum KOİ verimi sirasiyla, \%28, \%26 ve $\% 25$ olarak bulunurken, AKM giderme verimleri ise sirasiyla $\% 83, \% 86$ ve $\% 74$ olarak rapor edilmiştir [33]. 


\subsection{Koagülant Dozunun Etkisi}

Optimum pH aralı̆̆ında en uygun koagülant cinsi belirlendikten sonra koagülant dozajının tespiti için değişik konsantrasyonlarda koagülant dozajları ile kimyasal arıtılabilirlik deneyleri yürütülmüştür. Çalışmada en düşük koagülant miktarında \%48 KOİ giderme verimi, 2 gr/L dozajında ise $\% 87 \mathrm{KOİ} \mathrm{giderme} \mathrm{veriminin} \mathrm{elde}$ edildiği Şekil 3'de görülmektedir. Ayrıca 1,0 g/L koagülant dozajında elde edilen verim 1,5 g/L koagülant dozajında elde edilen verime çok yakındır. Bu nedenle, ekonomik etkinlik göz önüne alındığında, 1,0 g/L konsantrasyonu optimum konsantrasyon olarak seçilmiştir. 1,0 g/L koagülant (montmorillonit $+\mathrm{FeSO}_{4}$ ) dozajında \%92 oranında KOİ giderim verimi elde edilmiştir (Şekil 3).

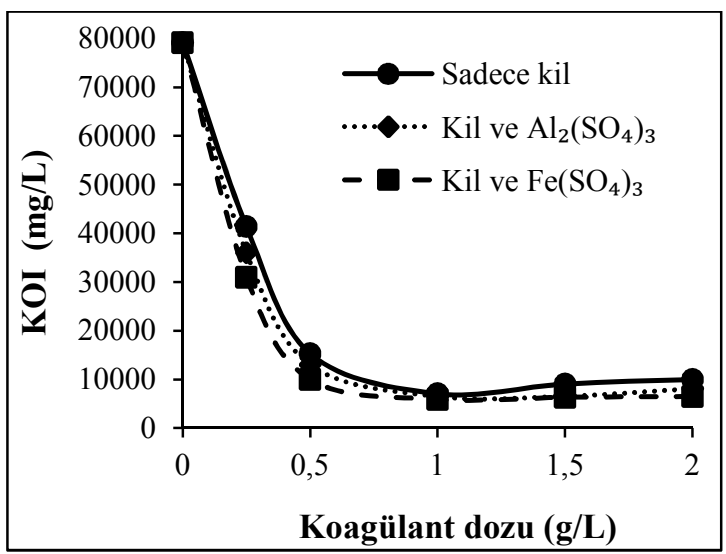

Şekil 3. KOİ giderimine koagülant dozunun etkisi

Sadece kil, alum+kil, demirsülfat+kil dozajının AKM giderimine etkisi Şekil 4'de gösterilmiştir. Optimum dozlarda sadece kil, alum+kil, demirsülfat+kil için elde edilen AKM giderim verimleri sirasiyla $\% 90, \% 91$ ve $\% 92$ olarak bulunmuştur (Şekil 4). Ayrıca 0,5 g/L koagülant dozajında elde edilen verim daha yüksek koagülant dozajında elde edilen verime çok yakındır. $\mathrm{Bu}$ nedenle, AKM gideriminde ekonomik etkinlik göz önüne alındığında, $0,5 \mathrm{~g} / \mathrm{L}$ konsantrasyonu optimum konsantrasyon olarak seçilmiştir. Peyniraltı suyunun kimyasal arıtımı için $\mathrm{Fe}\left(\mathrm{SO}_{4}\right) 3 \mathrm{H}_{2} \mathrm{O}$ kullanılarak yapılan bir çalışmada $\% 50, \mathrm{Fe}_{2}\left(\mathrm{SO}_{4}\right) 3 \mathrm{H}_{2} \mathrm{O}$ kullanıldı̆̆ giderme verimi elde edilmiştir. Koagülant olarak
$\mathrm{PAC}, \quad \mathrm{FeSO}_{4}, \quad \mathrm{Al}\left(\mathrm{SO}_{4}\right)_{2} .12 \mathrm{H}_{2} \mathrm{O}$ kullanıldığında pH 5,0-10 aralığında $100-5000 \mathrm{mg} / \mathrm{L}$ arasındaki koagülant dozlarında her üç koagülant için optimum pH 8,0 olarak belirlenmiştir [34].

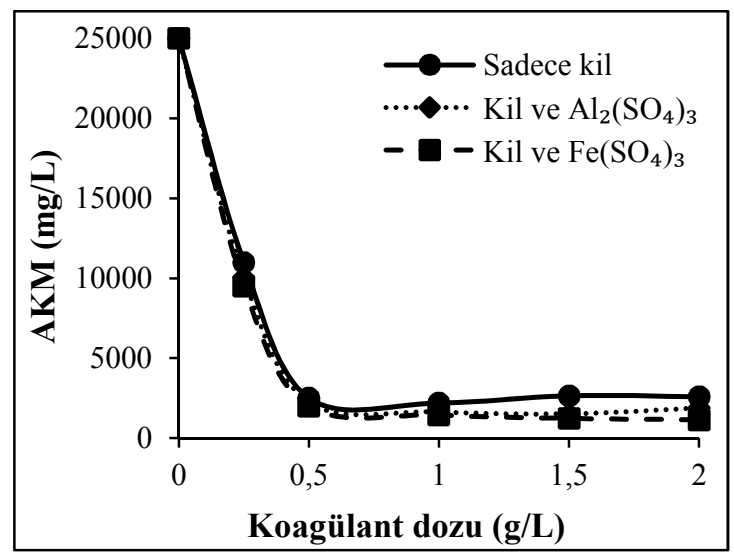

Şekil 4. AKM giderimine koagülant dozunun etkisi

\section{SONUÇ}

Süt endüstrisinden kaynaklanan peyniraltı suyunun koagülasyon/flokülasyon yöntemiyle arıtılmas1 incelenmiştir ve optimum işletme şartları belirlenmiştir. Üç farklı koagülantın farklı dozajlarda ve farklı pH'larda maksimum KOİ ve AKM giderim verimleri incelenmiştir. Optimum koagülant dozu 1,0 g/L ve $\mathrm{pH} \quad 7,0$ olarak belirlenmiştir. Sadece kil, Alum+kil, demirsülfat+kil için sırasıyla \%88, \%91 ve $\% 92$ KOİ giderim verimi ve $\% 89, \% 93$ ve $\% 95$ AKM giderim verimi elde edilmiştir. Koagülantların KOİ giderme mekanizması esas olarak şarj nötralizasyonu ve adsorpsiyonu nedeniyle gerçekleşmiştir. KOİ giderim verimliliğindeki artış, kolloidal partikülleri destabilize eden çeşitli hidroliz türlerinin konsantrasyonundaki artıştan kaynaklanmaktadır. Montmorillonit kilinin koagülasyon/flokülasyon prosesinde kullanılmasının olumlu sonuçlarının elde edilmesi bu kilin atıksuların arıtımında kullanımının arttırılmasını ve bu alanda daha fazla araştırma yapılmasını sağlamaktadır. Ayrıca bu malzemenin atıksu arıtımında yaygın olarak kullanılan koagülant ve flokülantlara alternatif bir malzeme olabileceği düşünülmektedir. 


\section{KAYNAKLAR}

1. Porwal, H.J., Mane, A.V., Velhal, S.G., 2015. Biodegradation of Dairy Effluent by Using Microbial Isolates Obtained from Activated Sludge, Water Resources and Industry, 9-1-15.

2. Öztürk, D., Aladağ, E., Yılmaz, A.E., Boncukcuğlu, R., Bayram, T., 2019. Mezbaha Atıksularının Karakterizasyonu ve Arıtılabilirliğinin Değerlendirilmesi, Iğdır Üniversitesi Fen Bilimleri Enstitüsü Dergisi, 9(2), 738-748.

3. Chokshi, K., Pancha, I., Ghosh, A., Mishra, S., 2016. Microalgal Biomass Generation by Phycoremediation of Dairy Industry Wastewater: An Integrated Approach Towards Sustainable Biofuel Production, Bioresource Technology, 221, 455-460.

4. Karnib, A., 2014. A Methodological Approach for Quantitative Assessment of the Effective Wastewater Management: Lebanon as a Case Study, Environmental Processes, 1(4), 483-495.

5. Rosa, D.R., Duarte, I.C.S., Saavedra, N.K., Varessche, M.B., Zaiat, M.C., 2009. Performance and Molecular Evaluation of an Anaerobic System with Suspended Biomass for Treating Wastewater With High Fat Content After Enzymatic Hydrolysis, Bioresource Technology, 100, 6170-6176.

6. Sarkar, B., Chakrabarti, P.P., Vijaykumar, A., Kale, V., 2006. Wastewater Treatment in Dairy Industries Possibility of Reuse, Desalination, 195(1-3), 141-152.

7. Aboubaraka, A.E., Aboelfetoh, E.F., Ebeid, E.Z.M., 2017. Coagulation Effectiveness of Graphene Oxide for the Removal of Turbidity from Raw Surface Water, Chemosphere, 181, 738-746.

8. Kılıç, A., 2006. Süt Endüstrisi Atıksularının Arıtımında Ardışık Kesikli Reaktörde (SBR) Hareketli Biofilm Uygulaması [thesis]. Selçuk Üniversity, Konya.

9. Güven, G., Perendeci, A., Tanyolaç, A., 2008. Electrochemical Treatment of Deproteinated Whey Wastewater and Optimization of Treatment Conditions with Response Surface Methodology, Journal of Hazardous Materials, 157, 69-78.
10. Gutierrez, J.L.R., Encina, P.A.G., Polanco, F.F., 1991. Anaerobic Treatment of Cheese Production Wastewater Using UASB Reactor. Bioresour Technol., 37(3),271-6.

11. Samal, K., Dash, R.R., Bhunia, P., 2017. Performance Assessment of a Canna Indica Assisted Vermifilter for Synthetic Dairy Wastewater Treatment, Process Safety and Environmental Protection, 111, 363-374.

12. Mateus, G.A.P., Formentini-Schmitt, D.M., Nishi L., Fagundes-Klen, M.R., Gomes, R.G., Bergamasco, R., 2017. Coagulation/Flocculation with Moringa Oleifera and Membrane Fitration for Dairy Wastewater Treatment. Water Air Soil Pollut. 228:342.

13. Özmetin, E., 2019. Süt Endüstrisi Atıksularının Kimyasal Arıtımının Yanıt Yüzey Yöntemi ile Optimizasyonu, Iğdır Üniversitesi Fen Bilimleri Enstitüsü Dergisi, 9(4), 1968-1976.

14. Sharma, B.R., Dhuldhoya, N.C., Merchant, U. C., 2006. Flocculants-an Ecofriendly Approach. Journal of Polymers and the Environment, 14, 195-2002.

15. Ingram, D.S., Vince-Prue, D., Gregory, P.J., 2003. Science and the Garden the Scientific Basis of Horticultural Practice. Blackwell Science Ltd., Oxford.

16. Li, H., Sheng, G., Teppen, B.J., Johnston, C.T., Boyd, S.A., 2003. Sorption and Desorption of Pesticides by Clay Minerals and Humic AcidClay Complexes. Soil Science Society of America Journal 67, 122-131.

17. Orhon, D., Görgün, E., Germirli, F., Artan, N., 1993. Biological Treatability of Dairy Wastewaters. Water Research, 27, 625-633.

18. Prazeres, A.R., Carvalho, F., Rivas, F.J., 2012. Cheese Whey Management: A Review, J. Environ Manage, 110, 48-68.

19. Farizoglu, B., Keskinler, B., Yildiz, E., Nuhoglu, A., 2007. Simultaneous Removal of C, N, P From Cheese Whey by Jet Loop Membrane Bioreactor (JLMBR). J. Hazard Mater, 146(1-2), 399-407.

20. Ghaly, A.E., Singh, R.K., 1989. Pollution Potential Reduction of Cheese Whey Through Yeast Fermentation. Appl Biochem Biotechnol, 22(2),181-203.

21. Malaspina, F., Cellamare, C.M., Stante, L., Tilche, A., 1996. Anaerobic Treatment of 
Cheese Whey With Downflow-Upflow Hybrid Reactor. Bioresour Technol, 55(2),131-9.

22. Ghaly, A.E., Kamal, M.A., 2004. Submerged Yeast Fermentation of Acid Cheese Whey for Protein Production and Pollution Potential Reduction. Water Res, 38(3),631-44.

23. Ferchichi, M., Crabbe, E., Gil, G.H., Hintz, W., Almadidy, A., 2005. Influence of Initial Ph on Hydrogen Production from Cheese Whey. J. Biotechnol, 120(4),402-9.

24. Blonskaja, V., Vaalu, T., 2006. Investigation of Different Schemes for Anaerobic Treatment of Food Industry Wastes in Estonia. Proc Est Acad Sci, 55(1), 14-28.

25. Ebrahimi, A., Najafpour, G.D., Mohammadi, M., Hashemiyeh B., 2010. Biological Treatment of Whey in An UASFF Bioreactor Following A Three-Stage RBC. Chem. Ind. Chem. Eng, 16(2),175-82.

26. Erkuş, A., Oygun, E., Türkmenoğlu, M., Aldemir, A., 2018. Boya Endüstrisi Atıksularının Karakterizasyonu. Yüzüncü Y1l Üniversitesi Fen Bilimleri Enstitüsü Dergisi, 23 (3), 308-319.

27. APHA (American Public Health Association), 1999. Standard Methods for The Examination of Water and Wastewater, $20^{\text {th }}$ ed., Washington D.C.

28. Su Kirliliği Kontrol Yönetmeliği (SKKY), 2004. Resmi Gazete, Resmi Gazete Tarihi: 31.12.2004, Resmi Gazete Sayısı: 25687.

29. Rivas, J., Prazeres, A.R., Carvalho, F., Beltran F., 2010. Treatment of Cheese Whey Wastewater: Combined CoagulationFlocculation and Aerobic Biodegradation, J. Agric. Food Chem. 58, 7871-7877.

30. Alkan, M., Demirbas, Ö., Doğan, M., 2005. Zeta Potential of Unexpanded and Expanded Perlite Samples in Various Electrolyte Media, Microporous and Mesoporous Materials, 84, 192-200.

31. Loloei, M., Alidadi, H., Nekonam, G., Kor, Y., 2014. Study of the Coagulation Process in Wastewater Treatment of Dairy Industries. Int J Env Health Eng. 3, 12.

32. Hasçakır, B., Dölgen, D., 2008. Kil Minerallerinin Atıksu Arıtımında Kullanılabilirliği: Kaolinit ile Organik Madde Giderimi, Ekoloji, 17(66), 47-54.
33. Gürtekin, E., 2011. Koagülasyon/Flokülasyon Prosesiyle Peyniraltı Suyunun Fizikokimyasal Arıtılabilirliği, Afyon Kocatepe Üniversitesi Fen Bilimleri Dergisi, 11, 17-22.

34. Pala, A., Sponza, D., 1994. Bir Süt Endüstrisi Atıksularının Karakterizasyonu ve Arıtma Sisteminin İncelenmesi. İTÜ 4. Endüstriyel Kirlenme Sempozyumu 94, 55-65, İstanbul. 